\title{
One hundred years of the Natural History Museum
}

\section{D.T. Donovan}

Alfred Waterhouse and the Natural History Museum. By Mark Girouard. Pp.64. ISBN 0-300-02578-5. (Yale University Press: 1981.) Hbk \$12.95, £4.95.

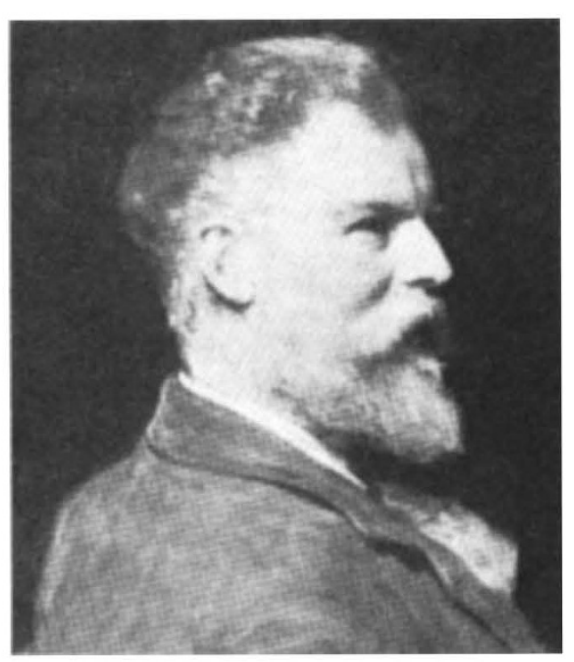

Alfred Waterhouse, 1830-1905, from a portrait by Sir William Orchardson.

THE Natural History Museum is the most splendid of the South Kensington museums; it has a vigour and coherence which is a tribute to the architect Alfred Waterhouse. So it comes as a surprise to learn that the building has a complicated history, and was nominally designed by somebody else.

The natural history collections were for long kept in Bloomsbury with the books and antiquities of the national museum. By the early nineteenth century antiquities were being added in large quantities, and by mid-century many thousands of natural history specimens were accumulating every year. The new British Museum building, begun by Robert Smirke in about 1823, was already too small by the time it was completed in about 1850 .

Mark Girouard begins his account with
Richard Owen's vision of a great new museum in 1858 , which was the origin of the present building. Removal of the natural history departments from Bloomsbury had been considered for some time, though a practical solution was not found until after 1851 with the development of South Kensington as a centre for education in the arts and sciences.

Owen, already famous for his contributions to comparative anatomy, had been appointed Superintendent of the Natural History Departments in 1856. In the same year, Antonio Panizzi, Keeper of Printed Books, was made Principal Librarian (i.e. Director) of the museum. Panizzi had long wanted to get rid of the natural history departments, and said so on every possible occasion. Yet even with Owen and Panizzi working towards the same end, it was another 25 years before the natural history collections were actually moved out of the Bloomsbury building. Initially, at least, almost the whole of the scientific establishment was opposed to such a move, and succeeded in influencing Parliament against it for some time.

In 1863, however, the Government bought the present site. On it stood the exhibition building of 1862 , built by the official architect Francis Fowke, and widely disliked. Parliament refused to purchase this building, which was demolished, and an architectural competition for a great new museum complex was held in 1864. It was won, to everyone's surprise, by Francis Fowke, but he died before his plan could be executed.

Alfred Waterhouse, newly arrived in London from successes in Manchester, was appointed to carry out Fowke's design, but it was not until 1873 that building was started. By this time only the Natural History Museum - about one-quarter of Fowke's complex - was actually going to be built, so the building had to be drastically re-designed. Girouard traces the influence of Fowke's design by comparing successive versions of the building. However, there is little perceptible resemblance between Fowke's drawings and the present building, and Waterhouse's standing as the architect is fully justified.

The plan of the museum, however, is neither Fowke's nor Waterhouse's; it stems from a sketch by Owen in 1859. This shows main east-west galleries with numerous galleries opening off them at right angles, the arrangement in the present-day museum.

Owen had always wanted his museum to be enriched by appropriate decoration. He and Waterhouse devised a scheme in which representations of living animals and plants adorned the west wing, intended for zoological collections, and extinct ones (restorations, not fossils) the east wing, where fossils and minerals were to be housed. Waterhouse's drawings were translated into models and cast in terracotta; comparative pictures in the book show how faithfully this was done.

The book has been sponsored by the Museum as part of the celebration of the centenary of its opening in 1881. This centenary is, unhappily, marked by controversy over the current proposal to demolish the rear single-storey galleries, thus destroying Owen's original plan.

Mark Girouard has written an attractive and interesting book which explains the history of the building and its architectural origins. It is well illustrated with pictures of the museum as it is, Waterhouse's working drawings and earlier versions of the design. Only the photographs of the interior are disappointing and do less than justice to the building. Otherwise, the book makes a handsome souvenir of this great embodiment of Victorian scientific achievement.

D.T. Donovan is Professor and Head of the Department of Geology at University College, University of London.

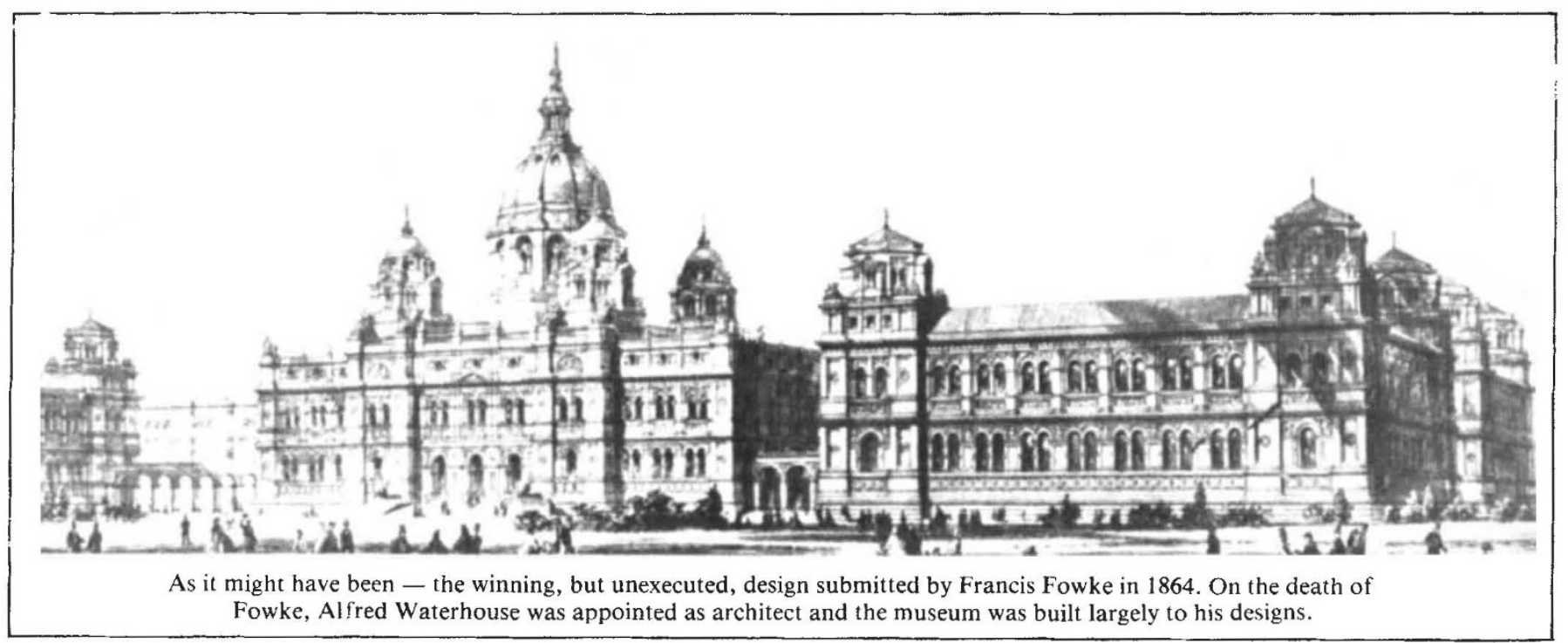

